Akses Online :

http:// jurnal.lp2msasbabel.ac.id

Dipublikasikan oleh :

Fakultas Tarbiyah IAIN Syaikh Abdurrahman Siddik Bangka Belitung

Info Artikel:

Diterima: 09/03/2017 Direvisi: 20/03/2017 01/06/2017

\title{
UPAYA PENINGKATAN KINERJA KEPALA SEKOLAH DALAM MENILAI KOMPETENSI PEDAGOGIK MENGGUNAKAN ALAT PENILAIAN KEMAMPUAN GURU DI SEKOLAH DASAR NEGERI 10 TEMPILANG DAN SEKOLAH DASAR NEGERI 11 TEMPILANG
}

\author{
Imrhon Harmi \\ Pengawas Sekolah Dasar
}

\section{ABSTRAK}

Penelitian ini bertujuan untuk mengetahui: (1) Tujuan diadakannya penelitian ini adalah untuk mengetahui upaya peningkatan kinerja Kepala Sekolah dalam menilai kompetensi pedagogik menggunakan alat penilaian kemampuan Guru di Sekolah Dasar Negeri 10 Tempilang dan Sekolah Dasar Negeri 11 Tempilang. Jenis penelitian ini adalah penelitian tindakan sekolah serta menggunakan metode penelitian tindakan kelas model John Elliot. Teknik pengumpulan data yang digunakan adalah wawancara, angket, observasi, dan dokumentasi. Hasil penelitian menunjukkan bahwa: Secara keseluruhan kepala sekolah di SDN 10 Tempilang dan kepala sekolah di SDN 11 Tempilang menyatakan penting untuk memiliki kinerja dalam menilai kompetensi pedagogik guru dengan cara alat penilaian kemampuan guru. Persentase yang sesuai dengan hal ini bahwa pada siklus 1 kepala sekolah SDN 10 Tempilang menyatakan 67,5\% dan pada siklus 2 menyatakan 77,5\% penting seorang kepala sekolah mengetahui cara menilai kompetensi pedagogic guru. Sedangkan, Persentase yang sesuai pada siklus 1 kepala sekolah di SDN 11 Tempilang menyatakan $70 \%$ dan pada siklus 2 menyatakan 72,5\% penting seorang kepala sekolah mengetahui cara menilai kompetensi pedagogik guru.Berkaitan dengan penilaian hasil observasi kinerja kepala sekolah dalam menilai kompetensi pedagogik guru dengan cara alat penilaian kemampuan guru. Persentase yang sesuai dengan hal ini bahwa pada siklus 1 kepala sekolah SDN 10 Tempilang menyatakan 64\% dan pada siklus 2 menyatakan 78\% baik atau optimal kepala sekolah mengetahui cara menilai kompetensi pedagogik guru. Sedangkan, Persentase yang sesuai pada siklus 1 kepala sekolah di SDN 11 Tempilang menyatakan 68\% dan pada siklus 2 menyatakan $76 \%$ baik atau optimal kepala sekolah mengetahui cara menilai kompetensi pedagogik guru. Sehingga secara umum untuk meningkatkan kinerja kepala sekolah dalam menilai kompetensi pedagogik pada SDN 10 Tempilang dan SDN 11 Tempilang dapat menggunakan alat penilaian kemampuan guru. 
Kata Kunci: Peningkatan, Kinerja, Pedagogik

\begin{abstract}
This study aims to determine: (1) The objective of this study was to determine the Principal improving performance in assessing pedagogical use assessment tools capabilities State Primary School Teachers 10 Tempilang and State Elementary School 11 Tempilang. This type of research is action research schools and research methods class action model of John Elliot. Data collection techniques used were interviews, questionnaires, observation, and documentation. The results showed that: Overall principal at SDN 10 Tempilang and principal at SDN 11 Tempilang said it was important to have a performance in assessing pedagogical competence of teachers by means of teacher assessment tool capabilities. The percentage that corresponds to it that the first cycle of the principal of SDN 10 Tempilang claimed $67.5 \%$ and in cycle 2 with $77.5 \%$ stating a principal's important to know how to assess teachers' pedagogic competence. Meanwhile, the corresponding percentage in cycle 1 principal at SDN 11 Tempilang stated $70 \%$ and in cycle $272.5 \%$ expressed a principal's important to know how to assess pedagogical competence assessment guru.Berkaitan with the observation of the performance of principals in assessing pedagogical competence of teachers by means of teacher assessment tool capabilities. The percentage that corresponds to it that the first cycle of the principal of SDN 10 Tempilang stated $64 \%$ and in cycle 2 said $78 \%$ good or optimal principals know how to assess teachers' pedagogical competence. Meanwhile, the corresponding percentage in cycle 1 principal at SDN 11 Tempilang stated $68 \%$ and in cycle 2 said $76 \%$ good or optimal principals know how to assess teachers' pedagogical competence. So generally to improve the performance of school principals in assessing pedagogical competence at SDN 10 and SDN 11 Tempilang can use teacher assessment tool capabilities.
\end{abstract}

Keywords: Improvement, Performance, Pedagogy 


\section{PENDAHULUAN}

Keberhasilan sebuah proses belajar mengajar, juga sangat didukung bagaimana kemampuan seorang guru dalam merancang dan menyusun sebuah perencanaan yang tertuang dalam rencana pelaksanaan pembelajaran. Perencanaan pembelajaran yang implementatif memerlukan kemampuan yang komprehensif. Kemampuan itulah yang dapat mengantarkan guru menjadi tenaga yang professional. Guru yang professional harus memiliki 5 (lima) kompetensi yang salah satunya adalah kompetensi penyusunan rencana pembelajaran. Namun dalam kenyataannya masih banyak guru yang belum mampu menyusun rencana pembelajaran sehingga hal ini secara otomatis berimbas pada kualitas output yang dihasilkan dalam proses pembelajaran.

Undang-Undang No. 14 tahun 2005 tentang Guru dan Dosen dan Peraturan Pemerintah No. 19 Tahun 2005 tentang Standar Nasional Pendidikan, pada dasarnya merupakan kebijakan pemerintah yang didalamnya memuat usaha pemerintah untuk menata dan memperbaiki mutu guru di Indonesia.

Guru adalah tenaga pendidik yang mempunyai tugas, fungsi, dan peran penting dalam mencerdaskan kehidupan bangsa. Guru yang profesional diharapkan mampu berpartisipasi dalam pembangunan nasional untuk mewujudkan insan Indonesia yang bertakwa kepada Tuhan YME, unggul dalam ilmu pengetahuan dan teknologi, memiliki jiwa estetis, etis, berbudi pekerti luhur, dan berkepribadian.

Menurut Peraturan Pemerintah No 19 Tahun 2005 yang mendeskripsikan bahwa Kompetensi pedagogik merupakan kemampuan dalam pengelolaan peserta didik yang meliputi: (a) pemahaman wawasan atau landasan kependidikan; (b) pemahaman terhadap peserta didik; (c) pengembangan kurikulum/silabus; (d) perancangan pembelajaran; (e) pelaksanaan pembelajaran yang mendidik dan dialogis; (f) evaluasi hasil belajar; dan (g) pengembangan peserta didik untuk mengaktualisasikan berbagai potensi yang dimilikinya.

Sehubungan dengan hal di atas yang merupakan kondisi ideal yang seyogyanya menjadi acuan bagi setiap guru dalam mengembangkan kompetensinya, namun kondisi nyata yang muncul dipermukaan tentu sangat berbeda dari kondisi ideal, yakni $80 \%$ guru sudah memiliki kompetensi pedagogik sesuai dengan acuan 7 indikator yang dipersyaratkan, namun $20 \%$ dikategorikan masih belum maksimal.

Dari $20 \%$ tenaga pendidik tersebut menjadi tanggungjawab penulis untuk melakukan pendekatan agar dapat menstimulus tenaga pendidk memiliki kompetensi dalam hal ini kompetensi pedagogik yang maksimal, maka upaya yang dilakukan penulis adalah dengan menerapkan suvervisi akademik menggunakan alat penilaian kompetensi guru. Tujuan 
pendekatan tersebut adalah memberikan ruang bagi guru agar secara bebas tanpa tekanan untuk melakukan evaluasi terhadap tanggungjawabnya baik sebagai individu maupun sebagai tenaga pendidik yang bertanggungjawab terhadap proses pembelajaran.

Dalam pengamatan di sekolah ditemukan beberapa permasalahan yaitu: (1) Rendahnya kompetensi guru dalam menyusun rencana pembelajaran khususnya silabus dan rencana pembelajaran, (2) Jumlah guru yang menyusun silabus dan RPP sebelum mengajar masih belum maksimal, (3) Kualitas silabus dan RPP yang disusun oleh guru masih belum baik, (4) Sulitnya kepala sekolah mengevaluasi kinerja guru, khususnya dalam penilaian kompetensi pedagogik seorang guru, dan (5) Sulitnya kepala sekolah mengevaluasi penilaian kompetensi secara komprehensif.

Dari beberapa permasalahan tersebut, secara khusus peneliti akan membatasi permasalahan yaitu sulitnya kepala sekolah mengevaluasi kinerja guru, khususnya dalam penilaian kompetensi pedagogik seorang guru.

Finch \& Crunkilton mengartikan kompetensi sebagai penguasaan terhadap suatu tugas, keterampilan, sikap, dan apresiasi yang diperlukan untuk menunjang keberhasilan. Dengan kata lain kompetensi tidak hanya mengandung pengetahuan, keterampilan dan sikap, namun yang penting adalah penerapan dari pengetahuan, keterampilan, dan sikap yang diperlukan tersebut dalam pekerjaan. ${ }^{1}$

Kompentensi diartikan juga suatu hal yang menggambarkan kualifikasi atau kemampuan seseorang, baik yang kualitatif maupun yang kuantitatif. ${ }^{2}$

Kemampuan individu dibentuk oleh dua faktor, yaitu faktor kemampuan intelektual dan kemampuan fisik. Kemampuan intelektual adalah kemampuan yang diperlukan untuk melakukan kegiatan mental sedangkan kemampuan fisik adalah kemampuan yang di perlukan untuk melakukan tugas-tugas yang menuntut stamina, kecekatan, kekuatan, dan keterampilan. Muhaimin menjelaskan kompetensi adalah seperangkat tindakan intelegenpenuh tanggung jawab yang harus dimiliki seseorang sebagai syarat untuk dianggap mampu melaksankan tugas-tugas dalam bidang pekerjaan tertentu. Sifat intelegen harus ditunjukan sebagai kemahiran, ketetapan, dan keberhasilan bertindak. Sifat tanggung jawab harus ditunjukkan

1 Mulyasa, Kurikulum Berbasis Kompetensi: Konsep, Karakteristik, dan Implementasi. (Bandung: PT Remaja Rosdakarya), 2003,hlm. 38

${ }^{2}$ Usman, Moh. Uzer, Menjadi Guru Profesional (Bandung: PT Remaja Rosdakarya), 1994, hlm. 1 
sebagai kebenaran tindakan baik dipandang dari sudut ilmu pengetahuan, teknologi maupun etika. $^{3}$

Kompetensi yang dimiliki oleh setiap guru akan menunjukkan kualitas guru dalam mengajar. Kompetensi tersebut akan terwujud dalam bentuk penguasaan pengetahuan dan profesional dalam menjalankan fungsinya sebagai guru. ${ }^{4}$ Kompentensi berarti suatu hal yang menggambarkan kualifikasi atau kemampuan seseorang, baik yang kualitatif maupun yang kuantitatif. Dalam hal ini, kompetensi diartikan sebagai pengetahuan, keterampilan, dan kemampuan yangdikuasai oleh seseorang yang telah menjadi bagian dari dirinya, sehingga ia dapat melakukan perilaku-perilaku kognitif, afektif, dan psikomotorik dengan sebaikbaiknya. ${ }^{5}$

Menurut Undang-undang No.14 tahun 2005 tentang Guru Dan Dosen pasal 10 ayat (1) kompetensi guru meliputi kompetensi pedagogik, kompetensi kepribadian, kompetensi sosial, dan kompetensi profesional yang diperoleh melalui pendidikan profesi. Salah satu kompetensi yang wajib dimiliki oleh seorang guru seperti diamanatkan dalam Peraturan pemerintah di atas adalah kompetensi pedagogik. Dalam Undang-undang No. 14 Tahun 2005 tentang Guru dan Dosen dikemukakan kompetensi pedagogik adalah "kemampuan mengelola pembelajaran peserta didik".

Kompetensi pedagogik sangat penting karena menjadi penentu bagi keberhasilan proses belajar yang langsung menyentuh kemampuan pembelajaran meliputi pengelolaan peserta didik, perencanaan, perencangan pelaksanaan, evaluasi hasil belajar dan pengembangan peserta didik terhadap potensi yang dimilikinya 1) menguasai karakteristik peserta didik 2) menguasai teori belajar 3) mengembangkan kurikulum 4) menyelenggarakan pembelajaran 5) memanfaatkan teknologi informasi 6) mengembangkan potensi peserta didik 7) berkomunikasi secara efektif 8) melaksanakan penilaian 9) memanfaatkan hasil penilaian untuk kepentingan pembelajaran 10) melakukan reflektif'.

Berkaitan dengan kegiatan Penilaian Kinerja Guru Buku 2 terdapat 7 (tujuh) aspek yang berkenaan dengan kompetensi pedagogik. Berikut ini disajikan ketujuh aspek kompetensi tersebut sebagai berikut: (1) Menguasai karakteristik peserta didik. Guru mampu

${ }^{3}$ Muhaimin, Paradigma Pendidikan Islam, (Bandung: PT Remaja Rosdakarya), 2004, hlm. 151

${ }^{4}$ Majid, Abdul, Perencanaan Pembelajaran: Mengembangkan Standar Kompetensi Guru. (Bandung: PT Remaja Rosdakarya), 2005, hlm.6

${ }^{5}$ Usman, Moh. Uzer, Menjadi Guru Profesional (Bandung: PT Remaja Rosdakarya), 1994, hlm. 1

${ }^{6}$ Mulyasa, Kurikulum Berbasis Kompetensi: Konsep, Karakteristik, dan Implementasi. (Bandung: PT Remaja Rosdakarya), 2003, hlm. 79 
mencatat dan menggunakan informasi tentang karakteristik peserta didik untuk membantu proses pembelajaran. Karakteristik ini terkait dengan aspek fisik, intelektual, sosial, emosional, moral, dan latar belakang sosial budaya, (2) Menguasasi teori belajar dan prinsipprinsip pembelajaran yang mendidik. Guru mampu menetapkan berbagai pendekatan, strategi, metode, dan teknik pembelajaran yang mendidik secara kreatif sesuai dengan str kompetensi guru. Guru mampu menyesuaikan metode pembelajaran yang sesuai dengan karakteristik peserta didik dan memotivasi mereka untuk belajar, (3) Pengembangan kurikulum. Guru mampu menyusun silabus sesuai dengan tujuan terpenting kurikulum dan menggunakan RPP sesuai dengan tujuan dan lingkungan pembelajaran. Guru mampu memilih, menyusun, dan menata materi pembelajaran yang sesuai dengan kebutuhan peserta didik, (4) Kegiatan pembelajaran yang mendidik. Guru mampu menyusun dan melaksanakan rancangan pembelajaran yang mendidik secara lengkap. Guru mampu melaksanakan kegiatan pembelajaran yang sesuai dengan kebutuhan peserta didik. Guru mampu menyusun dan menggunakan berbagai materi pembelajaran dan sumber belajar sesuai dengan karakteristik peserta didik. Jika relevan, guru memanfaatkan teknologi informasi komunikasi (TIK) untuk kepentingan pembelajaran, (5) Pengembangan potensi peserta didik. Guru mampu menganalisis potensi pembelajaran setiap peserta didik dan mengidentifikasi pengembangan potensi peserta didik melalui program embelajaran yang mendukung siswa mengaktualisasikan potensi akademik, kepribadian, dan kreativitasnya sampai ada bukti jelas bahwa peserta didik mengaktualisasikan potensi mereka, (6) Komunikasi dengan peserta didik. Guru mampu berkomunikasi secara efektif, empatik dan santun dengan peserta didik dan bersikap antusias dan positif. Guru mampu memberikan respon yang lengkap dan relevan kepada komentar atau pertanyaan peserta didik, (7) Penilaian dan Evaluasi. Guru mampu menyelenggarakan penilaian proses dan hasil belajar secara berkesinambungan. Guru melakukan evaluasi atas efektivitas proses dan hasil belajar dan menggunakan informasi hasil penilaian dan evaluasi untuk merancang program remedial dan pengayaan. Guru mampu menggunakan hasil analisis penilaian dalam proses pembelajarannya. ${ }^{7}$

\footnotetext{
${ }^{7}$ Depdiknas, Supervisi Akademik: Materi Pelatihan Penguatan Kemampuan Kepala Sekolah, (Jakarta: Depdiknas), 2010, hlm. 40-55
} 


\section{METODE PENELITIAN}

\section{Jenis Penelitian}

Penelitian ini merupakan penelitian tindakan sekolah. Metode penelitian adalah cara yang digunakan oleh peneliti dalam mengumpulkan data penelitiannya. ${ }^{8}$ Metode yang digunakan dalam penelitian ini adalah penelitian tindakan kelas. Pada penelitian ini mengadopsi dari desain PTK model John Elliot.

\section{Tempat dan Waktu Penelitian}

Penelitian ini dilaksanakan di SDN 10 Tempilang dan SDN 11 Tempilang. Waktu penelitian dilakukan pada semester genap tahun ajaran 2015/2016. Penelitian dilaksanakan dalam dua siklus yaitu, siklus I pada tanggal 11 Sampai 12 Februari 2016 dan siklus II pada tanggal 13 dan 14 Februari 2016. PTK ini dilakukan melalui 2 siklus, setiap siklus dilaksanakan mengikuti prosedur yaitu perencanaan, pelaksanaan, pengamatan, dan refleksi. Melalui kedua siklus tersebut terdapat peningkatan kinerja kepala sekolah melalui supervisi akademik dalam menilai kompetensi pedagogik menggunakan APKG.

\section{Subjek Penelitian}

Subjek penelitian adalah kepala sekolah SDN 10 Tempilang dan SDN 11 Tempilang yang berjumlah 2 orang.

\section{Teknik dan Instrumen Pengumpulan Data}

Instrumen dalam penelitian ini adalah peneliti itu sendiri (human instrument) yang berfungsi memilih informan sebagai sumber data, melakukan pengumpulan data, menilai kualitas data, analisis data, menafsirkan data dan membuat kesimpulan atas temuannya.

Teknik pengumpulan data dalam penelitian ini adalah penyebaran angket, observasi, wawancara dan dokumentasi. Angket untuk mengungkap kinerja kepala sekolah dalam menilai kompetensi pedagogik menggunakan APKG melalui supervisi akademik yang baik dan sesuai. Observasi digunakan untuk cross check data mengenai kinerja kepala sekolah dalam menilai kompetensi pedagogik menggunakan APKG melalui supervisi akademik yang baik dan sesuai. Wawancara digunakan untuk mendapatkan data tentang pemahaman kepala sekolah dalam meningkatkan kinerja kepala sekolah dalam menilai kompetensi pedagogik

\footnotetext{
${ }^{8}$ Suharsimi, Arikunto, Prosedur Penelitian, (Jakarta: PT. Rineka Cipta),2002, hlm.
} 
menggunakan APKG melalui supervisi akademik yang baik dan sesuai. Dokumentasi digunakan untuk menunjang kelengkapan data penelitian. Dokumentasi berupa dokumen penunjang penilaian kompetensi guru.

Suatu tindakan dikatakan berhasil apabila mampu mencapai kriteria yang telah ditentukan. Indikator meningkatnya kinerja kepala sekolah melalui supervisi akademik dalam menilai kompetensi pedagogik menggunakan alat penilaian kompetensi guru ditunjukkan jika kepala sekolah mampu mencapai peningkatan kinerja kepala sekolah melalui supervisi akademik dalam menilai kompetensi pedagogik menggunakan alat penilaian kompetensi guru 76\% berdasarkan masing-masing aspek yang diamati. Syaiful Bahri Djamarah dan Aswan Zain (2010: 107) menyatakan bahwa kriteria tingkat keberhasilan dapat dilihat pada tabel berikut:

Tabel 1. Kriteria Tingkat Keberhasilan Kepala Sekolah dalam \%

\begin{tabular}{|c|c|}
\hline Persentase & Keterangan \\
\hline $100 \%$ & Istimewa/maksimal \\
\hline $76 \%$ s.d. $99 \%$ & Baik sekali/optimal \\
\hline $60 \%$ s.d. $75 \%$ & Baik/minimal \\
\hline$<60 \%$ & Kurang \\
\hline
\end{tabular}

Indikator penilaian peningkatan kinerja kepala sekolah melalui supervisi akademik dalam menilai kompetensi pedagogik menggunakan alat penilaian kompetensi guru ditetapkan oleh peneliti yaitu adalah 75. Apabila guru dalam tabel observasi maupun indikator yang lainnya yang mendapat nilai yang sesuai indikator kelengakapan mengajar dengan kriteria ABCD yaitu nilai 75 ke atas mencapai $76 \%$ maka penggunaan alat penilaian kompetensi guru dalam menilai kompetensi pedagogik menggunakan supervisi akademik secara baik dan benar.

Dalam penelitian ini untuk menguji keabsahan data dilakukan dengan teknik triangulasi data. Triangulasi adalah teknik pemeriksaan keabsahan data yang memanfaatkan sesuatu yang lain di luar data itu untuk keperluan pengecekan, atau sebagai pembanding terhadap data itu ${ }^{9}$

9 Iin Tri Rahayu dan Tristiadi Ardi Ardani,Observasi dan Wawancara (Jawa Timur: Bayumedia Publishing), 2004, hlm.142 
Penelitian ini menggunakan teknik triangulasi data atau triangulasi sumber data serta triangulasi metode. Triangulasi data dimaksudkan agar dalam pengumpulan data menggunakan banyak sumber data. Triangulasi ini membandingkan dan mengecek balik derajat kepercayaan suatu informasi yang diperoleh melalui waktu dan alat yang berbeda dalam metode kualitatif. Dalam penelitian ini triangulasi data dilakukan dengan membandingkan data hasil wawancara dengan data hasil pengamatan yang telah dilakukan. Sedangkan triangulasi metode menggunakan berbagai metode pengumpulan data untuk menggali data sejenis. Triangulasi metode ini menggunakan strategi pengecekan derajat kepercayaan beberapa sumber data dengan metode yang sama.$^{10}$

\section{Teknik Analisis Data}

Analisis data dalam penelitian tindakan sekolah ini dilakukan dengan dua analisis data, antara lain:

\section{Analisis Data Kualitatif}

Data yang bersifat kualitatif yang diperoleh dari hasil wawancara dianalisis dengan analisis kualitatif. Teknik analisis kualitatif yang digunakan adalah model interaktif Miles \& Huberman. Miles \& Huberman (1992), mengemukakan bahwa aktivitas dalam analisis data kualitatif dilakukan secara interaktif dan berlangsung secara terus-menerus sampai tuntas, sehingga datanya sudah jenuh. Aktivitas dalam analisis data, yaitu data reduction, data display, dan conclusion drawing/verification (Sugiyono, 2010: 337-345). ${ }^{11}$

1. Data reduction (Reduksi data)

Data yang diperoleh dari lapangan jumlahnya cukup banyak, untuk itu maka perlu dicatat secara teliti dan rinci. Seperti telah dikemukakan, semakin lama peneliti ke lapangan maka jumlah data akan semakin banyak dan kompleks. Mereduksi data berarti merangkum, memilih hal yang pokok, memfokuskan pada hal-hal yang penting, dicari tema dan polanya. Dengan demikian data yang direduksi akan memberikan gambaran yang lebih jelas, dan mempermudah peneliti untuk melakukan pengumpulan data selanjutnya, dan mencarinya bila diperlukan.

10 Iin Tri Rahayu dan Tristiadi Ardi Ardani,Observasi dan Wawancara (Jawa Timur: Bayumedia Publishing), 2004, hlm.143

${ }^{11}$ Sugiyono, Metode Penelitian Pendidikan Pendekatan Kuantitatif, Kualitatif, dan R\&D. (Bandung: Alfabeta), 2010, hlm. 337-345 
2. Data display (Penyajian data)

Setelah data direduksi, maka langkah selanjutnya adalah mendisplaykan data. Dalam penelitian kuantitatif penyajian data ini dapat dilakukan dalam bentuk tabel, grafik, pie chart, pictogram dan sejenisnya. Melalui penyajian data tersebut, maka data terorganisasikan, tersusun dalam pola hubungan, sehingga akan lebih mudah dipahami. Dalam penelitian kualitatif, penyajian data bisa dilakukan dalam bentuk uraian singkat, bagan, hubungan antar kategori, flowchart dan sejenisnya

3. Conclusion Drawing/verification (Penarikan kesimpulan atau verifikasi)

Langkah ketiga dalam analisis data kualitatif menurut Miles and Huberman adalah penarikan kesimpulan dan verifikasi. Kesimpulan awal yang dikemukakan masih bersifat sementara, dan akan berubah bila tidak ditemukan bukti-bukti yang kuat yang mendukung pada tahap pengumpulan data berikutnya. Tetapi apabila kesimpulan yang dikemukakan pada tahap awal, didukung oleh bukti-bukti yang valid dan konsisten saat peneliti kembali ke lapangan mengumpulkan data, maka kesimpulan yang dikemukakan merupakan kesimpulan yang kredibel.

\section{Analisis data kuantitatif}

Secara kuantitatif, data dianalisis dengan persentase (Presentages Correction). Besarnya nilai yang diperoleh kepala sekolah adalah presentase dari skor maksimum ideal yang seharusnya dicapai jika 100\% sesuai (Ngalim Purwanto, 2009: 102). ${ }^{12}$ Perhitungan persentase digunakan rumus:

$$
N P=\frac{R}{S M} X 100
$$

Keterangan:

$\mathrm{NP}=$ nilai persen yang diharapkan

$\mathrm{R}=$ skor mentah yang diperoleh

$\mathrm{SM}=$ skor maksimal ideal

$100=$ bilangan tetap

\footnotetext{
${ }^{12}$ Ngalim Purwanto, Evaluasi Hasil Belajar, (Yogyakarta: Pustaka Pelajar), 2009, hl. 102
} 
Tabel 2. Kriteria Kinerja Kepala Sekolah Melalui Supervisi Akademik Menggunakan APKG

Dalam Menilai Kompetensi Pedagogik

\begin{tabular}{|c|c|}
\hline Persentase & $\begin{array}{c}\text { Kriteria Penilaian } \\
\text { Kompetensi } \\
\text { Pedagogik }\end{array}$ \\
\hline$>80 \%$ & Sangat tinggi \\
\hline $60-80 \%$ & Tinggi \\
\hline $40-60 \%$ & Sedang \\
\hline $20-40 \%$ & Rendah \\
\hline$<20 \%$ & Sangat Rendah \\
\hline
\end{tabular}

\section{HASIL PENELITIAN}

Adapun hasil yang diperoleh dari penelitian tindakan sekolah yang berjudul Upaya Peningkatan Kinerja Kepala Sekolah Melalui Supervisi Akademik Dalam Menilai Kompetensi Pedagogik Menggunakan Alat Penilaian Kompetensi Guru Di Sekolah Dasar Negeri 10 Tempilang Dan Sekolah Dasar Negeri 11 Tempilang, dapat peneliti jelaskan sebagai berikut:

Deskripsi Hasil Wawancara Sebelum Menilai Kompetensi Pedagogik Menggunakan Alat Penilaian Kompetensi Guru Dilakukan

Pentingnya memiliki kompetensi bagi seorang guru di SDN 10 Tempilang dan SDN 11 Tempilang sehingga kepala sekolah perlu mengetahui konsep kompetensi itu sendiri sebelum melakukan penilaian terhadap guru-guru di sekolah. Wawancara dilakukan pada 2 kepala sekolah. Bahwa pada wawancara tanggal 9 Februari 2016 bahwa A mengungkapkan:

Menurut pemahaman saya kompetensi itu merupakan suatu kemampuan seorang guru dalam segala hal terkait bidang ilmunya masing-masing.

Kemudian, bahwa pada wawancara tanggal 10 Februari 2016 bahwa B mengungkapkan:

Kompetensi merupakan kemampuan atau kecakapan seorang guru dalam kelas selama mengajar serta kemampuan guru ketika berinteraksi diluar kelas misalnya berinteraksi dengan guru-guru lainnya.

Berkaitan dengan pemahaman kepala sekolah tentang kompetensi pedagogik guru, bahwa pada wawancara tanggal 9 Februari 2016 bahwa A mengungkapkan: 
Kompetensi pedagogik merupakan kemampuan seorang guru dalam memahami siswanya, kemudian kemampuan seorang guru dalam perencanaan dan pelaksanaan pembelajaran dikelas serta kemampuan guru menilai siswa setelah proses belajar mengajar di kelas.

Diperkuat oleh pernyataan kepala sekolah B, bahwa pada wawancara tanggal 10 Februari 2016 mengungkapkan:

Menurut saya kompetensi pedagogik yaitu seorang guru memiliki kemampuan dalam perencanaan dan pelaksanaan pembelajaran, kemampuan guru menilai siswa serta memiliki kemampuan mengembangkan potensi siswanya dikelas.

Selanjutnya, berkaitan dengan pemahaman kepala sekolah tentang langkah-langkah menilai kompetensi pedagogik guru, bahwa pada wawancara tanggal 9 Februari 2016 bahwa A mengungkapkan:

Saya terkadang kesulitan menilai kompetensi pedagogik guru sebab hal ini diperlukan strategi yang tepat sehingga kepala sekolah dapat menilai secara keseluruhan komponen pedagogi guru tersebut.

Diperkuat oleh pernyataan kepala sekolah B, bahwa pada wawancara tanggal 10 Februari 2016 mengungkapkan:

Menurut saya langkah-langkah kompetensi pedagogik terlalu rumit untuk menilainya, diperlukan instrumen yang valid agar dapat menilai secara komprehensif kemampuan pedagogik guru seperti instrumen yang ditawarkan oleh peneliti yaitu menggunakan alat penilaian kompetensi guru khususnya penilaian kompetensi pedagaogik guru.

Hasil Angket Sebelum Menilai Kompetensi Pedagogik Menggunakan Alat Penilaian Kompetensi Guru Dilakukan

Tabel 3. Penilaian kompetensi pedagogik menggunakan APKG melalui supervisi akademik yang baik dan sesuai

\begin{tabular}{|c|c|c|}
\hline No & Alternatif Jawaban & $\begin{array}{c}\text { Persentase } \\
(\%)\end{array}$ \\
\hline 1 & Sangat Setuju & 0 \\
\hline 2 & Setuju & 62 \\
\hline 3 & Tidak Setuju & 38 \\
\hline 4 & Sangat Tidak Setuju & 0 \\
\hline \multicolumn{2}{|c|}{ Jumlah } & 100 \\
\hline
\end{tabular}

Berdasarkan tabel. 3 menyatakan bahwa $62 \%$ kepala sekolah menyadari bahwa setuju atau penting serta berada pada kategori tinggi untuk memiliki kemampuan menilai 
kompetensi pedagogik guru dan tidak setuju 38\% atau berada pada kategori rendah menyatakan bagi kepala sekolah untuk memiliki kemampuan menilai kompetensi pedagogik guru. Hal ini sangatlah beralasan karena dengan memiliki kemampuan tersebut membantu kelancaran dalam supervisi akademik sekolah tersebut secara menyeluruh dan efektifitas waktu kapala sekolah.

Siklus 1 Peningkatan Kinerja Kepala Sekolah Melalui Supervisi Akademik Dalam Menilai Kompetensi Pedagogik Menggunakan Alat Penilaian Kompetensi Guru Di Sekolah Dasar Negeri 10 Tempilang Dan Sekolah Dasar Negeri 11 Tempilang

Hasil penelitian ini diperoleh melalui angket dan observasi. Namun untuk mengetahui pencapaian peningkatan tindakan dilihat dari hasil observasi.. Data penelitian yang dilakukan di SDN 10 Tempilang dan SDN 11 Tempilang ini diperoleh dari kepala sekolah.

Dalam penjabaran hasil penelitian siklus 1 ini dipaparkan hasil penelitian tindakan pada kepala sekolah SDN 10 Tempilang, kemudian dilanjutkan dengan hasil penelitian tindakan pada kepala sekolah SDN 10 Tempilang, setelah itu hasil data pada siklus satu ini dipaparkan secara bersamaan untuk mengetahui hasil persentase keseluruhannya.

Pertama hasil angket penelitian tindakan siklus 1 pada kepala sekolah di SDN 10 Tempilang. Dari hasil penelitian dengan data angket diketahui bahwa:

Tabel 4. Hasil Angket Penelitian Tindakan Siklus 1

Pada Kepala Sekolah di SDN 10 Tempilang

\begin{tabular}{|c|c|c|c|}
\hline \multirow{2}{*}{ No } & $\begin{array}{c}\text { Skor } \\
\text { Kepala } \\
\text { Sekolah }\end{array}$ & $\begin{array}{c}\text { Persentase } \\
(\%)\end{array}$ & Klasifikasi \\
\hline \multirow{2}{*}{1} & 20 & $25 \%$ & $\begin{array}{c}\text { Sangat } \\
\text { Tinggi }\end{array}$ \\
\cline { 2 - 4 } & 54 & $67,5 \%$ & Tinggi \\
\cline { 2 - 4 } & 6 & $7,5 \%$ & Rendah \\
\cline { 2 - 4 } & 0 & $0 \%$ & $\begin{array}{c}\text { Sangat } \\
\text { Rendah }\end{array}$ \\
\hline
\end{tabular}

Dari tabel. 4 dapat kita lihat bahwa hasil data angket menunjukan pentingnya kinerja kepala sekolah melalui supervisi akademik dalam menilai kemampuan kompetensi pedagogik menggunakan berada pada kategori tinggi. Artinya dari data angket yang disebar kepada kepala sekolah di SDN 10 Tempilang pemahamannya tentang hal tersebut secara keseluruhan baik atau pada kategori tinggi. 
Untuk menindak lanjuti hasil data angket di atas dilakukan observasi terhadap ketercapaian peningkatan kinerja kepala sekolah. Dari hasil penelitian menggunakan pengumpulan data observasi pada berkaitan dengan penilaian tentang kinerja kepala sekolah melalui supervisi akademik dalam menilai kemampuan kompetensi pedagogik yaitu:

Tabel 5. Hasil Observasi Penelitian Tindakan Siklus 1

Pada Kepala Sekolah di SDN 10 Tempilang

\begin{tabular}{|c|c|c|c|}
\hline No & $\begin{array}{c}\text { Skor } \\
\text { Kepala } \\
\text { Sekolah }\end{array}$ & Persentase & Klasifikasi \\
\hline 1 & 32 & $64 \%$ & $\begin{array}{c}\text { Baik/ } \\
\text { Minimal }\end{array}$ \\
\hline
\end{tabular}

Dari tabel. 5 dapat kita lihat bahwa kinerja kepala sekolah melalui supervisi akademik dalam menilai kemampuan kompetensi pedagogik berada pada kategori baik/minimal sesuai dengan criteria tingkat keberhasilan kepala sekolah.

Kedua, hasil penelitian tindakan siklus 1 pada kepala sekolah di SDN 11 Tempilang. Dari hasil penelitian dengan data angket diketahui bahwa:

Tabel 6. Hasil Angket Penelitian Tindakan Siklus 1 Pada Kepala Sekolah di SDN 11 Tempilang

\begin{tabular}{|c|c|c|c|}
\hline No & $\begin{array}{c}\text { Skor } \\
\text { Kepala } \\
\text { Sekolah }\end{array}$ & $\begin{array}{c}\text { Persentase } \\
(\%)\end{array}$ & Klasifikasi \\
\hline \multirow{2}{*}{1} & 15 & $18,75 \%$ & $\begin{array}{c}\text { Sangat } \\
\text { Tinggi }\end{array}$ \\
\cline { 2 - 4 } & 56 & $70 \%$ & Tinggi \\
\cline { 2 - 4 } & 9 & $11,25 \%$ & Rendah \\
\cline { 2 - 4 } & 0 & $0 \%$ & $\begin{array}{c}\text { Sangat } \\
\text { Rendah }\end{array}$ \\
\hline
\end{tabular}

Dari tabel. 6 dapat kita lihat bahwa hasil data angket menunjukan pentingnya kinerja kepala sekolah melalui supervisi akademik dalam menilai kemampuan kompetensi pedagogik menggunakan berada pada kategori tinggi. Artinya dari data angket yang disebar kepada 
kepala sekolah di SDN 11 Tempilang pemahamannya tentang hal tersebut secara keseluruhan baik atau pada kategori tinggi.

Untuk menindak lanjuti hasil data angket di atas dilakukan observasi terhadap ketercapaian peningkatan kinerja kepala sekolah. Dari hasil penelitian menggunakan pengumpulan data observasi pada berkaitan dengan penilaian tentang kinerja kepala sekolah melalui supervisi akademik dalam menilai kemampuan kompetensi pedagogik yaitu:

Tabel 7. Hasil Observasi Penelitian Tindakan Siklus 1

Pada Kepala Sekolah di SDN 11 Tempilang

\begin{tabular}{|c|c|c|c|}
\hline No & $\begin{array}{c}\text { Skor } \\
\text { Kepala } \\
\text { Sekolah }\end{array}$ & Persentase & Klasifikasi \\
\hline 1 & 34 & $68 \%$ & $\begin{array}{c}\text { Baik/ } \\
\text { Minimal }\end{array}$ \\
\hline
\end{tabular}

Dari tabel.7 dapat kita lihat bahwa kinerja kepala sekolah melalui supervisi akademik dalam menilai kemampuan kompetensi pedagogik berada pada kategori baik/minimal sesuai dengan kriteria tingkat keberhasilan kepala sekolah.

Siklus I1 Peningkatan Kinerja Kepala Sekolah Melalui Supervisi Akademik Dalam Menilai Kompetensi Pedagogik Menggunakan Alat Penilaian Kompetensi Guru Di Sekolah Dasar Negeri 10 Tempilang Dan Sekolah Dasar Negeri 11 Tempilang

Hasil penelitian ini diperoleh melalui angket dan observasi. Namun untuk mengetahui pencapaian peningkatan tindakan dilihat dari hasil observasi.. Data penelitian yang dilakukan di SDN 10 Tempilang dan SDN 11 Tempilang ini diperoleh dari kepala sekolah.

Dalam penjabaran hasil penelitian siklus 2 ini dipaparkan hasil penelitian tindakan pada kepala sekolah SDN 10 Tempilang, kemudian dilanjutkan dengan hasil penelitian tindakan pada kepala sekolah SDN 10 Tempilang, setelah itu hasil data pada siklus satu ini dipaparkan secara bersamaan untuk mengetahui hasil persentase keseluruhannya.

Pertama hasil penelitian tindakan siklus 2 pada kepala sekolah di SDN 10 Tempilang. Dari hasil penelitian dengan data angket diketahui bahwa: 
Tabel 8. Hasil Angket Penelitian Tindakan Siklus 2

Pada Kepala Sekolah di SDN 10 Tempilang

\begin{tabular}{|c|c|c|c|}
\hline No & $\begin{array}{c}\text { Skor } \\
\text { Kepala } \\
\text { Sekolah }\end{array}$ & $\begin{array}{c}\text { Persentase } \\
(\%)\end{array}$ & Klasifikasi \\
\hline \multirow{2}{*}{1} & 18 & $22,5 \%$ & $\begin{array}{c}\text { Sangat } \\
\text { Tinggi }\end{array}$ \\
\cline { 2 - 4 } & 62 & $77,5 \%$ & Tinggi \\
\cline { 2 - 4 } & 0 & $0 \%$ & Rendah \\
\cline { 2 - 4 } & 0 & $0 \%$ & $\begin{array}{c}\text { Sangat } \\
\text { Rendah }\end{array}$ \\
\hline
\end{tabular}

Dari table. 8 dapat kita lihat bahwa hasil data angket menunjukan pentingnya kinerja kepala sekolah melalui supervisi akademik dalam menilai kemampuan kompetensi pedagogik menggunakan berada pada kategori tinggi. Artinya dari data angket yang disebar kepada kepala sekolah di SDN 10 Tempilang pemahamannya tentang hal tersebut secara keseluruhan baik atau pada kategori tinggi.

Untuk menindak lanjuti hasil data angket di atas dilakukan observasi terhadap ketercapaian peningkatan kinerja kepala sekolah. Dari hasil penelitian menggunakan pengumpulan data observasi pada berkaitan dengan penilaian tentang kinerja kepala sekolah melalui supervisi akademik dalam menilai kemampuan kompetensi pedagogik yaitu:

Tabel 9. Hasil Observasi Penelitian Tindakan Siklus 2

Pada Kepala Sekolah di SDN 10 Tempilang

\begin{tabular}{|c|c|c|c|}
\hline No & $\begin{array}{c}\text { Skor } \\
\text { Kepala } \\
\text { Sekolah }\end{array}$ & Persentase & Klasifikasi \\
\hline 1 & 39 & $78 \%$ & $\begin{array}{c}\text { Baik Sekali/ } \\
\text { Optimal }\end{array}$ \\
\hline
\end{tabular}

Dari tabel. 9 dapat kita lihat bahwa kinerja kepala sekolah melalui supervisi akademik dalam menilai kemampuan kompetensi pedagogik berada pada kategori baik sekali atau optimal. 
Kedua, hasil penelitian tindakan siklus 2 pada kepala sekolah di SDN 11 Tempilang. Dari hasil penelitian dengan data angket diketahui bahwa:

Tabel 10. Hasil Angket Penelitian Tindakan Siklus 2

Pada Kepala Sekolah di SDN 11 Tempilang

\begin{tabular}{|c|c|c|c|}
\hline \multirow{2}{*}{ No } & $\begin{array}{c}\text { Skor } \\
\text { Kepala } \\
\text { Sekolah }\end{array}$ & $\begin{array}{c}\text { Persentase } \\
(\%)\end{array}$ & Klasifikasi \\
\hline \multirow{3}{*}{1} & 13 & $16,25 \%$ & $\begin{array}{c}\text { Sangat } \\
\text { Tinggi }\end{array}$ \\
\cline { 2 - 4 } & 58 & $72,5 \%$ & Tinggi \\
\cline { 2 - 4 } & 9 & $11,25 \%$ & Rendah \\
\cline { 2 - 4 } & 0 & $0 \%$ & $\begin{array}{c}\text { Sangat } \\
\text { Rendah }\end{array}$ \\
\hline
\end{tabular}

Dari table. 10 dapat kita lihat bahwa hasil data angket menunjukan pentingnya kinerja kepala sekolah melalui supervisi akademik dalam menilai kemampuan kompetensi pedagogik menggunakan berada pada kategori tinggi. Artinya dari data angket yang disebar kepada kepala sekolah di SDN 11 Tempilang pemahamannya tentang hal tersebut secara keseluruhan baik atau pada kategori tinggi.

Untuk menindak lanjuti hasil data angket di atas dilakukan observasi terhadap ketercapaian peningkatan kinerja kepala sekolah. Dari hasil penelitian menggunakan pengumpulan data observasi pada berkaitan dengan penilaian tentang kinerja kepala sekolah melalui supervisi akademik dalam menilai kemampuan kompetensi pedagogik yaitu:

Tabel 11. Hasil Observasi Penelitian Tindakan Siklus 2

Pada Kepala Sekolah di SDN 11 Tempilang

\begin{tabular}{|l|l|l|l|}
\hline No & $\begin{array}{l}\text { Skor } \\
\text { Kepala } \\
\text { Sekolah }\end{array}$ & Persentase & Klasifikasi \\
\hline 1 & 38 & $76 \%$ & $\begin{array}{l}\text { Baik Sekali/ } \\
\text { Optimal }\end{array}$ \\
\hline
\end{tabular}


Dari table. 11 dapat kita lihat bahwa kinerja kepala sekolah melalui supervisi akademik dalam menilai kemampuan kompetensi pedagogik berada pada kategori baik sekali atau optimal.

\section{PEMBAHASAN}

Berdasarkan hasil penelitian sebelum tindakan dilakukan bahwa dalam hasil wawancara dapat dideskripsikan secara umum, kompetensi merupakan suatu kemampuan seorang guru dalam segala hal terkait bidang ilmunya masing-masing serta kemampuan atau kecakapan seorang guru dalam kelas selama mengajar dan kemampuan guru ketika berinteraksi diluar kelas misalnya berinteraksi dengan guru-guru lainnya. Kemudian berkaitan dengan kompetsni pedagogik bahwa semua kepala sekolah secara umum mengungkapkan kompetensi pedagogik merupakan kemampuan seorang guru dalam memahami siswanya, kemudian kemampuan seorang guru dalam perencanaan dan pelaksanaan pembelajaran dikelas serta kemampuan guru menilai siswa setelah proses belajar mengajar di kelas dan memiliki kemampuan mengembangkan potensi siswanya dikelas.

Berkaitan dengan pemahaman kepala sekolah tentang langkah-langkah menilai kompetensi pedagogik guru, dapat dideskripsikan secara umum bahwa kepala sekolah pada umumnya kesulitan menilai kompetensi pedagogik guru sebab hal ini diperlukan strategi yang tepat sehingga kepala sekolah dapat menilai secara keseluruhan komponen pedagogi guru tersebut. Langkah-langkah kompetensi pedagogik terlalu rumit untuk menilainya, diperlukan instrumen yang valid agar dapat menilai secara komprehensif kemampuan pedagogik guru seperti instrumen yang ditawarkan oleh peneliti yaitu menggunakan alat penilaian kompetensi guru khususnya penilaian kompetensi pedagogik guru.

Sejalan dengan deskripsi umum di atas bahwa kepala sekolah SDN 10 dan 11 Tempilang setuju untuk dilaksanakan penerapan penilaian kompetensi pedagogik, diharapkan dengan adanya tindakan dapat mempermudah kepala sekolah dalam menilai kompetensi pedagogik gur-guru. Dari hasil angket diketahui bahwa 62\% kepala sekolah setuju dengan penilaian APKG tersebut dan 38\% tidak setuju. Namun, secara umum dapat kita deskripsikan bahwa perlu diadakan tindakan kepada kepala sekolah untuk dapat menilai kompetensi pedagogik guru-guru di sekolah.

Berdasarkan data awal di atas, maka dilaksanakanlah tindakan pada siklus 1 dan siklus 2, yang mana terjadi peningkatan dalam persentase angket maupun hasil penilaian observasinya. Dari angket yang disebarkan kepada semua kepala sekolah di SDN 10 Tempilang dan kepala sekolah SDN 11 Tempilang dapat dilihat bahwa pada siklus 1 terdapat 
nilai persentase yang diisi oleh kepala sekolah SDN 10 Tempilang yaitu 67,5\% berada pada kategori tinggi, 25\% berada pada kategori sangat tinggi, dan 7,5\% berada pada kategori rendah. Namun, secara umum dapat diseskripsikan bahwa hasil angket tentang pentingnya penilaian kompetensi pedagogic dengan cara APKG berada pada kategori tinggi atau penting untuk dilakukan. Kemudian berdasarkan tindakan pada siklus 2 mengungkapkan bahwa pentingnya kinerja kepala sekolah melalui supervisi akademik dalam menilai kemampuan kompetensi pedagogik menggunakan APKG berada pada kategori tinggi yaitu 77,5\% tinggi dan 22,5\% kategori sangat tinggi. Artinya dari data angket yang disebar kepada kepala sekolah di SDN 10 Tempilang mulai siklus 1 ke siklus 2 terjadi peningkatan persentase yaitu awalnya $67,5 \%$ ke $77,5 \%$.

Dari angket yang disebarkan kepada kepala sekolah kepala sekolah SDN 11 Tempilang dapat dilihat bahwa pada siklus 1 terdapat nilai persentase yaitu $70 \%$ berada pada kategori tinggi, 18,75\% berada pada kategori sangat tinggi, dan 11,25\% berada pada kategori rendah. Namun, secara umum dapat diseskripsikan bahwa hasil angket tentang pentingnya penilaian kompetensi pedagogic dengan cara APKG berada pada kategori tinggi atau penting untuk dilakukan. Kemudian berdasarkan tindakan pada siklus 2 mengungkapkan bahwa pentingnya kinerja kepala sekolah melalui supervisi akademik dalam menilai kemampuan kompetensi pedagogik menggunakan APKG berada pada kategori tinggi yaitu 72,5\%, 16,25\% kategori sangat tinggi, dan 11,25\% rendah. Artinya dari data angket yang disebar kepada kepala sekolah di SDN 10 Tempilang mulai siklus 1 ke siklus 2 terjadi peningkatan persentase yaitu awalnya $70 \%$ ke $72,5 \%$.

Berdasarkan penilaian hasil observasi kinerja kepala sekolah melalui supervisi akademik dalam menilai kemampuan kompetensi pedagogik menggunakan APKG maka dilaksanakanlah tindakan pada siklus 1 dan siklus 2, yang mana terjadi peningkatan dalam persentase hasil penilaian observasinya. Dari penilaian hasil observasi yang digunakan untuk menilai kinerja kepala sekolah dalam menilai kompetensi pedagogic menggunakan APKG kepada semua kepala sekolah di SDN 10 Tempilang dan kepala sekolah SDN 11 Tempilang dapat dilihat bahwa pada siklus 1 terdapat nilai persentase kepala sekolah SDN 10 Tempilang yaitu $64 \%$ berada pada kategori baik atau minimal. Secara umum dapat diseskripsikan bahwa hasil penilaian observasi tentang penilaian kompetensi pedagogic dengan cara APKG berada pada kategori baik atau minimal dilakukan oleh kepala sekolah. Kemudian berdasarkan tindakan pada siklus 2 mengungkapkan bahwa kinerja kepala sekolah melalui supervisi akademik dalam menilai kemampuan kompetensi pedagogik menggunakan APKG berada pada kategori baik sekalii atau optimal yaitu $78 \%$. Artinya dari data penilaian hasil observasi 
kepala sekolah di SDN 10 Tempilang mulai siklus 1 ke siklus 2 terjadi peningkatan persentase yaitu awalnya $64 \% \%$ ke $78 \%$.

Kemudian, berdasarkan penilaian hasil observasi kinerja kepala sekolah melalui supervisi akademik dalam menilai kemampuan kompetensi pedagogik menggunakan APKG maka dilaksanakanlah tindakan pada siklus 1 dan siklus 2, yang mana terjadi peningkatan dalam persentase hasil penilaian observasinya. Dari penilaian hasil observasi yang digunakan untuk menilai kinerja kepala sekolah dalam menilai kompetensi pedagogic menggunakan APKG kepada semua kepala sekolah di SDN 11 Tempilang dapat dilihat bahwa pada siklus 1 terdapat nilai persentase kepala sekolah SDN 11 Tempilang yaitu 68\% berada pada kategori baik atau minimal. Secara umum dapat diseskripsikan bahwa hasil penilaian observasi tentang penilaian kompetensi pedagogic dengan cara APKG berada pada kategori baik atau minimal dilakukan oleh kepala sekolah. Kemudian berdasarkan tindakan pada siklus 2 mengungkapkan bahwa kinerja kepala sekolah melalui supervisi akademik dalam menilai kemampuan kompetensi pedagogik menggunakan APKG berada pada kategori baik sekalii atau optimal yaitu $76 \%$. Artinya dari data penilaian hasil observasi kepala sekolah di SDN 10 Tempilang mulai siklus 1 ke siklus 2 terjadi peningkatan persentase yaitu awalnya $68 \% \%$ ke $76 \%$.

\section{SIMPULAN DAN SARAN}

\section{Simpulan}

Berdasarkan hasil penelitian dan data yang dihimpun serta diinterpretasikan oleh penulis, maka dapat disimpulkan sebagai berikut:

Secara keseluruhan kepala sekolah di SDN 10 Tempilang dan kepala sekolah di SDN 11 Tempilang menyatakan penting untuk memiliki kinerja dalam menilai kompetensi pedagogik guru dengan cara alat penilaian kemampuan guru. Persentase yang sesuai dengan hal ini bahwa pada siklus 1 kepala sekolah SDN 10 Tempilang menyatakan 67,5\% dan pada siklus 2 menyatakan $77,5 \%$ penting seorang kepala sekolah mengetahui cara menilai kompetensi pedagogic guru. Sedangkan, Persentase yang sesuai pada siklus 1 kepala sekolah di SDN 11 Tempilang menyatakan 70\% dan pada siklus 2 menyatakan 72,5\% penting seorang kepala sekolah mengetahui cara menilai kompetensi pedagogic guru.

Berkaitan dengan penilaian hasil observasi kinerja kepala sekolah dalam menilai kompetensi pedagogik guru dengan cara alat penilaian kemampuan guru. Persentase yang sesuai dengan hal ini bahwa pada siklus 1 kepala sekolah SDN 10 Tempilang menyatakan $64 \%$ dan pada siklus 2 menyatakan $78 \%$ baik atau optimal kepala sekolah mengetahui cara 
menilai kompetensi pedagogic guru. Sedangkan, Persentase yang sesuai pada siklus 1 kepala sekolah di SDN 11 Tempilang menyatakan 68\% dan pada siklus 2 menyatakan $76 \%$ baik atau optimal kepala sekolah mengetahui cara menilai kompetensi pedagogic guru. Sehingga secara umum untuk meningkatkan kinerja kepala sekolah dalam menilai kompetensi pedagogic pada SDN 10 Tempilang dan SDN 11 Tempilang dapat menggunakan alat penilaian kemampuan guru.

\section{Saran}

Ada beberapa saran yang perlu penulis kemukakan berkaitan dengan upaya peningkatan kinerja kepala sekolah dalam Menilai kompetensi pedagogik menggunakan alat penilaian kompetensi guru di Sekolah Dasar Negeri 10 Tempilang dan Sekolah Dasar Negeri 11 Tempilang yaitu: (1) Bagi kepala sekolah hendaknya secara berkala melakukan pemeriksaan terhadap perencanaan mengajar Guru, agar para Guru senantiasa melaksanakan proses pembelajaran secara terencana, (2) Kepala sekolah perlu melakukan bimbingan kepada para Guru perencanaan dan pelaksanaan pembelajarannya terutama kepada Guru yang masih pemula atau Guru yang mengajar bukan pada bidangnya karena ada kecenderungan kurangnya kompetensi atau kemampuan dalam hal pedagogic, (3) Guru yang pengetahuan dan pengalamannya masih kurang agar dapat meminta bimbingan atau berkoordinasi dengan teman sejawat yang lebih berpengalaman atau meminta bimbingan kepada kepala sekolah atau yang ditunjuk sehingga ada peningkatan kompetensi secara komprehensif. 
Zurnal TARBAWY

Jurnal Pendidikan Islam
Volume 4 Nomor 1, Juni 2017 Akses Online: http:// jurnal.lp2msasbabel.ac.id

\section{Referensi}

Depdiknas. 2010. Supervisi Akademik: Materi Pelatihan Penguatan Kemampuan Kepala Sekolah. Jakarta: Depdiknas.

Iin Tri Rahayu dan Tristiadi Ardi Ardani. 2004. Observasi dan Wawancara. Jawa Timur: Bayumedia Publishing.

Majid, Abdul. 2005. Perencanaan Pembelajaran: Mengembangkan Standar Kompetensi Guru. Bandung: PT Remaja Rosdakarya.

Muhaimin. 2004. Paradigma Pendidikan Islam. Bandung: PT Remaja Rosdakarya.

Mulyasa. 2003. Kurikulum Berbasis Kompetensi: Konsep, Karakteristik, dan Implementasi. Bandung: PT Remaja Rosdakarya. 2011. Standar Kompetensi dan Sertifikasi Guru. Bandung: Remaja Rosdakarya.

Peraturan Pemerintah Nomor 19 Tahun 2005 tentang Standar Nasional Pendidikan.

Sugiyono. 2010. Metode Penelitian Pendidikan Pendekatan Kuantitatif, Kualitatif, dan R\&D. Bandung: Alfabeta.

Suharsimi, Arikunto. 2002. Prosedur Penelitian. Jakarta: PT. Rineka Cipta.

Syaiful Bahri Djamarah dan Aswan Zain. 2010. Strategi Belajar Mengajar. Jakarta: Rineka Cipta.

Undang-Undang Nomor 14 Tahun 2005 tentang Guru dan Dosen.

Usman, Moh. Uzer. 1994. Menjadi Guru Profesional. Bandung: PT Remaja Rosdakarya 